\title{
Domains That Lead To Happiness At Workplace
}

\author{
Khairunesa Isa, Zahrul Akmal Damin, Lutfan Jaes, Azmi Abdul Latiff, Abdul Halim Abdul \\ Rahman, Abu Khari A’ain, Naim Maslan, Siti Solehah Tenah
}

\begin{abstract}
Happiness among employees can give significant impact on performance of any organization. Thus, it is important to know factors that lead to happiness at workplace. This study aims to identify domains that contribute to happiness at workplace among staff at University A. A total of 535 employees were selected using random sampling technique to fill out a questionnaire. Results analyzed using SPSS show that social domain is the main contributor to happiness among staff at University $A$ with a mean value of 3.108. This is followed by individual domain (mean $=2.996$ ) and organization domain (mean $=2.721)$. Therefore this study shows that social domain which refers to relationship among individual, family and society has a high impact on happiness among employees at workplace. Meanwhile job environment in individual domain and work environment in organization domain have a moderate impact on happiness among employees at workplace. Thus, this research suggests that organizations should consider assisting employees in having work life balance by restricting working hours and providing time for their employees to do volunteer work in the society.
\end{abstract}

Index Terms: happiness, happiness at workplace, social domain, job environment and work life balance.

\section{INTRODUCTION}

Happiness is a basic need in the life of human beings. Many work hard to ensure they can afford to have a happy living (Elfida, 2008). Happiness is is a situation that drives individuals towards positive emotion that will lead them to behave positively in line with their expectation (Seligman, 2005). Biawas et al., (2007) defined happiness as a quality of the whole life of human being whether in the aspects of health, occupation, shelter and income that can improve their lives. their workplace. Human beings need to feel happy especially when they are at their workplace as it will influence their work performance level as well the performance of their organizations they are working at. Happiness can be defined as the frequency of positive and negative combined responses that impact the satisfaction

Revised Manuscript Received on April 19, 2019.

Khairunesa Isa, Centre for Curriculum and Public Studies, Universiti Tun Hussein Onn Malaysia, Batu Pahat, Johor, Malaysia.

Zahrul Akmal Damin, Centre for Curriculum and Public Studies, Universiti Tun Hussein Onn Malaysia, Batu Pahat, Johor, Malaysia.

Lutfan Jaes, Centre for Curriculum and Public Studies, Universiti Tun Hussein Onn Malaysia, Batu Pahat, Johor, Malaysia

Azmi Abdul Latif, Centre for Language Studies, Universiti Tun Hussein Onn Malaysia, Batu Pahat, Johor, Malaysia

Abdul Halim Abdul Rahman, Registrar, Universiti Tun Hussein Onn Malaysia, Batu Pahat, Johor, Malaysia

Abu Khari A'ain, Faculty of Electrical and Electronic Engineering, Universiti Tun Hussein Onn Malaysia, Batu Pahat, Johor, Malaysia

Naim Maslan, Registrar, Universiti Tun Hussein Onn Malaysia, Batu Pahat, Johor, Malaysia

Siti Solehah Tenah, Research Management Centre, Universiti Tun Hussein Onn Malaysia, Batu Pahat, Johor, Malaysia
Majority of adults spend almost the entire of their days at

level to the life of human beings (Myers \& Diener, 1995; Diener et al., 1999). Happy individuals are inclined to provide support to other individuals. They are also creative, pro social, love charity and lead a healthy life (Diener \& Dean, 2007). They are able to avoid themselves from the threats of stress, pressure and hypertension (Amirullah, 2017).

\section{PROBLEM STATEMENT}

The Indeed Job Happiness Index (2016) reported that Malaysia is positioned at the sixth place out of ten countries which have the highest number of job unhappiness where workers are not happy in doing their work. Such happiness index is related to work satisfaction which indicates that Malaysian workers are not happy to work as they face the problem of work-life balance and other issues at their organizations. In-Tune Outsourcing (2012) discovered that 78 percent of Malaysian workers are not happy with their current occupation. This is mainly due to factors such as job scope that is too complex and low wage that they earn.

Technology-based work system is another factor that influences the level of happiness among staff at organizations. Ranstad's Workmonitor Report (2018) showed that extreme use of technology such the requirement to report job status to employers through WhatsApp caused psychological effect to the staff. Furher more, forcing them to give prompt answers via email at night or over the weekend could cause pressure on the staff. It does not only disturb their quality time with their family but might also cause the staff to feel that they are not trusted, oppressed and putting them under pressure as they need to give quick response.

According to Amirullah (2017), the state of unhappiness will influence the life of staff in general either physically or mentally. In Malaysia, there are 62.3 percent cases of staff who do not disclose that they have mental illness. 61 percent of the staff blame themselves for suffering from the mental problem. The 3rd National Health and Morbidity Report 2006 reported that 3 out of 26 millions of the Malaysian population were reportedly suffering from mental illness. Such mental illness might cause the individuals to suffer and experience unhappiness especially while carrying out their work. Such a circumstance could give a major adverse impact to productivity and staff wellness as well as the organizations themselves.

Meanwhile, Nazelira and Norfadzilah (2017) discovered other factors that could influence staff emotion and affect the staff psychologically and emotionally. These include not getting recognition for their achievement, not getting the 
trust from their superior, salary scale that does not match the burden placed upon them and ideas that are not appreciated by the employers. A research at University A found out situations such as frequency of taking medical leaves, not punctual for work, truancy, high medical cost, schizophrenia, doing part time jobs, taking too many annual leaves and frequent cases being referred to counseling centre are symptoms of unhappy staff at the university who reportedly faced and felt unhappy at the workplace.

Nevertheless, Sin and Lyubomirsky (2009) suggested several approaches that could be carried out to improve happiness among staff in organizations especially in the aspects of their feeling, behavior and thought. In line with the findings, The Jobs Central on Work Happiness Indicator 2012 Report discovered five major domains that influence staff happiness at workplace that included salary, work balance, opportunity for career development, attractive job specification and opinion from staff that is acceptable by employers. Henceforth, this research is carried to determine domains that could contribute to staff happiness at organizations by focusing on individual, organizational and

\section{A. Research Objective}

The research has four objectives:

i. To identify domains that contribute to staff happiness at University A.

ii. To determine individual domain that contributes to staff happiness at University A.

iii. To determine organizational domain that contributes to staff happiness at University A.

iv. To determine individual social domain that contributes to staff happiness at University A.

\section{LITERATURE REVIEW}

Happiness at workplace can be referred to as a situation where staff are healthy and happy in carrying out their work (Wesarat, Sharif dan Abdul Majid, 2014). This situation is important as happy staff are more productive in doing other work (Wok and Hashim, 2015). Furthermore, staff who are happy with their working condition will help to improve the performance of their organizations (Hongyi Hung, 2016).

The subjectivity of the concept of happiness that is defined according to individuals has caused measurement on happiness as difficult to be done and happiness is concluded as a static object. There are individuals who define happiness at workplace as something that can be physically seen such as ergonomic workplace environment (Zafir, 2010). Nevertheless, there are many who define happiness at workplace in more subjective but achievable contexts such as interaction with fellow staff, (Wesarat, Majid and Sharif, 2015), Staib, 2009; Suojanen, 2012), work happiness (Meriam, 2017; Ariati, 2010 andAlfarisi, 2010), good organizational management (Mindtools, 2009), task activity and organizational culture (Wesarat, Majid dan Sharif, 2015) and many others.

Factors that influence work happiness are varied among staff. In general work happiness is influenced by factors such as salary received, job promotional opportunity, quality of supervision and office mates (Smith, Kendall and Hullin, 1969). However, each of the factors gives different impact social domains.

on each staff equally. The difference is influenced by the individuals' personal factor depending on how they define work satisfaction. According to Mitchell (1979), high salary and challenging work are important factors that lead to staff satisfaction.

\section{A. Domain that Contribute to Staff Happiness}

Happiness at workplace is a positive feeling that is always felt by staff. This feeling emerges when the staff are capable of managing and implementing their work to the extent where they are capable of producing output that give them self satisfaction (Pryce and Jones, 2010). According to a perception of contemporary management, silo mentality needs to be broken up in order to maintain staff motivation, happiness and happiness at workplace (Muna and Atasya, 2013). Nevertheless, happiness at workplace does only refer to individuals' intrinsic value but also involves other individual extrinsic values such including organizational atmosphere (Zafir, 2010), relationship with other individuals (Carr, 2004; Wesarat, Majid and Sharif, 2015; Wulandri and Widyastuti, 2014; and other factors that are directly related to work such as work satisfaction (Meriam, 2017), autonomy (Berlian and Lukman Hakim, 2014), leadership, salary, rewards and others.

A research by Wok and Hashim (2015) revealed that communication is a factor that is inclined to achieving the basic of happiness at workplace. According to them, Wok and Hashim (2015), communication does not only refer to interaction between fellow staff but also involves interaction with environment outside their organizations such as their neighbors and other social friends. Besides achieving happiness, social interaction also helps to improve competency among workers in construction sector (Fahmi et al., 2018). According to, (2001) this is due to the surrounding that the presence of an individual could catalyze other people to do jobs that could not be done before. Meanwhile, Murti (2013) stated that social support is one of the requirements in achieving work satisfaction besides one's personal characteristics, family relationship and feeling at peace with his work. Relationship with other individuals and formal as well as informal environment are strongly believed to influence individual happiness (Meriam, 2007; and Siska and Ami, 2014).

Work satisfaction is an emotional state that can be linked to positive and negative assessment of working experience (Malik, 2010). When work satisfaction is achieved, work productivity will also improve (Abd. Samad and Gooi, 2005). A Dual Factor of Work Satisfaction Theory by Herzberg stated that high performance will result in work satisfaction. The two factors mentioned by Herzberg are namely health and growth factors. Researchers such as Herzberg (1959), McGregor (1960), Arggeris (1964) and Maslow (1970) emphasized that work satisfaction contributes to one's individual development and organizational performance.

According to Staib (2009), four aspects that can make staff feel happy at their work place are internal strength and 
motivation as well as relationship with other people. A research by Siska and Ami (2014) showed that positive relationship with other people is more influential in giving happiness to staff than other aspects such as staff performance, workplace environment and staff health. These findings show how influential the individual factor in ensuring staff happiness at workplace. The ability of the staff to adapt themselves in the social space can serve as a platform for them to share their feeling and pressure that they are experiencing.

Research by Job Street.com (2018) discovered that factors such work location and condition as well as organizational reputation are the main reasons behind staff satisfaction at workplace. In fact, many Malaysians feel happy with the atmosphere at workplace compares to their home. This shows how influential the factors are on staff happiness. Similar to the opinion, Zafir (2010) stated that it is important to establish an ergonomic workplace condition as it could reduce stress in an organization. According to Dul and Newmann (2009), ergonomic does not only focus on occupational safety and health but also supports business strategy in order to maintain competitiveness in the organization. Moreover, according to Sutton and Rafaeli (1987) and Bao et al., (2009) also shared the opinion that the physical state of workstation which include air circulation, temperature are determiners to staff happiness at organizations.

\section{B. The Happiness Model}

The happiness model as presented in Figure 2.1 explains that happiness is a subjective feeling. The model comprises three domains that mould happiness at workplace namely individual, organizational and social domains. Individuals who feel that they have the stability in the three domains are seen as having the capability to achieve happiness at workplace. In the individual domain context, individuals will feel happy when they are satisfied with their work atmosphere, experience career development, possess the necessary skills related to their job specifications and have the ability to adapt. All these factors have strong relationships with staff happiness level as they are inculcated at personal level.

A balanced organizational atmosphere and individual support are also seen as contributors to the happiness level among organizational staff. According to the Model of Happiness, support from organizational management, intimacy among staff, role of occupation and work-life balance have strong relationships with the happiness among organizational staff. These work atmosphere elements are likely to show more balance in the lives of staff and minimize their stress level. Organizational atmosphere that support staff career development is also able to be a medium in contributing to staff happiness at their organizations.

The social domain has also been identified as having the ability to contribute to staff happiness at their organizations. Supports from family members and social system heavily influence staff happiness. Existing interactions in the social environment can make staff to be more open in work atmosphere. Besides enabling staff to share arising issues, such a condition also contributes to the creation of staff lighting, workspace design, sound system, extreme

network among staff. Knowledge sharing that emerges at the social level encourages individuals to be more open and this method is seen as capable of reducing stress among the staff. The social interactions that exist between individuals and other members of society can create the feeling of being trusted and appreciated amongst them. Through this approach, individuals will feel happy in their lives.

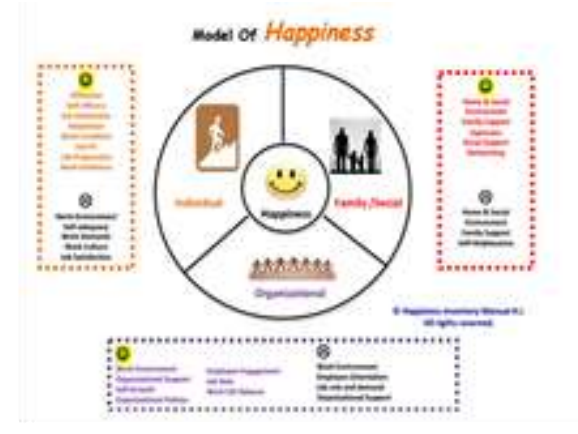

Figure 2.1 :Model Of Happiness

\section{METHODOLOGY}

\section{A. Design and Sampling}

The research was a descriptive survey. A total of 535 respondents were selected through simple random sampling from the total population. The samples comprised academicians and administrative staff of University A.

\section{B. $\quad$ Pilot Test Result}

A pilot test was randomly carried out on 30 staff of University A comprising academic and administrative staff. Three variables in this research including individual, organizational and social domains were tested on their reliability. Analysis showed that the value of Cronbach Alpha $(\alpha)$ values for all variables were within the range of 0.703 to 0.856 . The specifications for Cronbach Alpha reality coefficient values for each domain are presented in Table 1 .

Table 1: Cronbach Alpha Reliability Coefficient Value in the Pilot Research

\begin{tabular}{|c|c|c|}
\hline Variable & Construct & $\begin{array}{c}\text { Alpha } \\
\text { Cronbach } \\
\text { Value } \\
(\mathrm{a}=\mathbf{3 0})\end{array}$ \\
\hline \multirow{4}{*}{$\begin{array}{l}\text { Individual } \\
\text { Domain }\end{array}$} & Self Satisfaction & 0.779 \\
\hline & Work Atmosphere & 0.856 \\
\hline & Career development at work place & 0.723 \\
\hline & Self-adaptability at work place & 0.829 \\
\hline \multirow{4}{*}{$\begin{array}{l}\text { Organizational } \\
\text { Domain }\end{array}$} & Organizational support & 0.728 \\
\hline & Work atmosphere at workplace & 0.703 \\
\hline & Level of task & 0.783 \\
\hline & Organizational policy & 0.846 \\
\hline \multirow{3}{*}{ Social Domain } & Social atmosphere & 0.754 \\
\hline & Social support & 0.747 \\
\hline & $\begin{array}{l}\text { Relarionship among family } \\
\text { members, social and inviduals }\end{array}$ & 0.779 \\
\hline
\end{tabular}

\section{Research Instrument}

This descriptive survey employed observation and 
questionnaire as research instruments. Part A refers to demography of the respondents such as age, length of service and grade of position. On the other hand, Part B serves to identify domains that contribute to staff happiness at University A by focusing on three factors namely individual, social and organizational. Likert scale with 4 option answers was used to evaluate a statement based on score distribution as presented in Table 2. Besides, it was also used to avoid respondents from giving answers such as 'unsure' or' disagree'. The frequency of the respondents to choose option at scale 3 such as 'unsure' and 'disagree' will put the credibility of the research in doubt.

Table 2 : Likert Scale for Level of Happiness

\begin{tabular}{lc}
\hline ITEM & SCALE \\
\hline Strongly disagree & 1 \\
Disagree & 2 \\
Agree & 3 \\
Strongly agree & 4 \\
\hline
\end{tabular}

\section{RESULTS AND FINDINGS}

\section{A. Demography of Respondents}

Majority of the respondents $(52.4$ percent, $\mathrm{n}=280)$ are between the adult age of (31-40) followed by 28.7 percent (n $=154$ ) of the respondents between the age of $41-50$ years old. This shows that most of the staff at University A are within the age range when they are physically still capable of carrying out their duties, thinking maturely in handling matters, tasks and decisions. Meanwhile, majority of the respondents $(n=330,61.7 \%)$ were found to have served at University A between 11 to 30 years. Most of them have served between $(n=292,54.5 \%)$ between 11 to 20 years, 21 to 24 years $(n=30,5.6 \%)$ and 25 to 30 years $(n=8,1.5 \%)$. These findings show that majority of the respondents are in the 'mature' stage to serve at University A in which they understand the direction and long term objectives of the University.

The analysis also discovered that the research was mostly represented by the academic staff of grade 51 to 54 with a total of 135 staff $(25.3 \%)$ followed by staff of grade 41 to 45 with a total of 61 people $(11.4 \%)$. Most of the academic staff of grade 51 to 54 are senior lecturers and $\mathrm{PhD}$ holders while those of grade 41 to 45 comprised tutors, language teachers, instructors and lecturers who have yet to complete their PhD studies. Only 4 respondents $(0.7 \%)$ were of JUSA $\mathrm{A}, \mathrm{B}$ and $\mathrm{C}$ involved on the research. For the administrative staff, more than half of the respondents $(n=207,38.7 \%)$ are staff of Support 1 grade (Group C). This was followed by those of Management and Operation grade (Group A \& B) with a total of 88 respondents (16.4\%) and 40 (7.5) respondents of Support 2 grade.

\section{B. Domains That Contribute to Staff Happiness}

Table 3 shows the analysis for mean scores for the domains that contribute to staff happiness at University A. The analysis shows that social domain had a high score with the mean value of 3.108 contribution to staff happiness. This shows that the social element plays a significant role determining staff happiness while working and serving the organizations. Meanwhile, the individual and organizational domains were at the moderate level with the mean values of 2.996 and 2.721 respectively.

The individual domain mostly refers to management and self-adaptability of staff to job specifications and work atmosphere. In this context, the ability of staff to manage themselves while working could help to reduce their stress and contribute to happiness at workplace. Meanwhile, the moderate score for the organizational domain shows that improvements need to be done to the atmosphere and ecological system of University A in order for the domain to contribute to staff happiness while working.

Table 3 : Mean Score for Domains that Contribute to Happiness

\begin{tabular}{|l|c|c|}
\hline \multicolumn{1}{|c|}{ Variables } & Mean & Score Value \\
\hline Individual & 2.996 & Moderate \\
\hline $\begin{array}{l}\text { Organizationa } \\
1\end{array}$ & 2.721 & Moderate \\
\hline Social & 3.108 & High \\
\hline
\end{tabular}

The social domain for this research was made up of three sub domains namely social atmosphere, social support and relationships between family and social with the individuals. Generally, the score value for the social domain was a high level with the mean score of 3.108 in contributing to staff happiness at University A. This shows that the respondents are happy when they are surrounded by individuals who are close and trustworthy to them such as family members and friends. According to Carr (2004), individual happiness depends on individuals' assessment on cognitive satisfaction with other domains including family and their social circle. The respondents were found to feel happy if they have ample time to carry out social activities with family members and friends either involving formal or informal interactions. The social interaction element was also found to have significant value in determining individual happiness. Siska and Ami (2014) explained that this is because positive relationship with other people is the biggest factor that makes people to feel happy at their workplace.

Happiness within individuals is a concept that directs individuals' positive attitude especially when the carry out activities they like. (Seligman, 2005). Thus, it is not strange that for some individuals to love taking part in voluntary and societal activities such as 'rewang' (a community-based collaborative activity) and 'rukun tetangga'(neighborhood watch). It can be said that individuals with a high happiness level generally have a satisfying social life and spend much time by socializing (Meriam, 2017). Interactions that exist in social life usually fulfill individuals' needs and wants besides able to inculcate happiness levels within the individuals. According to Argyle (2000 and 2001), close relationships among individuals were found to have strong correlation with happiness and wellness in life. In supporting the finding, the Neo behaviorism Theory (Miller and Dollard, 1950; and Sears et al., 1957), stated that 
individuals' behavior is strongly influenced by environmental factors especially by the social and cultural elements.

The relationships between family and society with individuals were found to be influential in determining a high level of happiness among the individuals. Family was found to have a strong relationship in determining individual happiness (Puteri, 2009). As such, research by Seligman (2002) and Carr (2004) discovered that marriage element is seen as having a bigger impact compare financial element in influencing individuals' happiness. Through marriage, the physiological needs of individuals will naturally fulfilled and the individuals only have to focus to other needs in their search for the objectives in life. In supporting the findings, Seligman (2002) and Carr (2004), Ma'arof (2001) stated the important to have a spouse or partner in life as it is a basic requirement in life. Mingling with others will help to fulfill individuals' physiological and psychological needs (Ma'arof, 2001). In supporting the statement, Anggun (2015) confirmed that the utmost happiness of every individual is when they have friend or spouse who is not only their husband or wife but also their social friends and colleagues.

The social factor such as neighborhood and friends are also influential to the respondents' happiness. Simon et al., (2010) said that individuals with good friends will feel happier as good friends always support each other. The social relationship should not only be seen in the friendship or face to face context. In fact interactions in the virtual world were also found to be influential in determining happiness as long as the interactions could create socialization space among individuals (Snow, 2013). A research by Zakaria et al., (2012) found out that social environment factors including parents and peers have a hand in moulding one's identity. Thus, it can be said that the social environment factor is capable of influencing individuals' happiness factor as every individual has his own concept of happiness. (Veenhoven, 2003; Youssef and Luthans, 2007; Kesebir and Diener, 2008; Fisher, 2010; Oishi et. al., 2011; Saliman and Hosainian, 2012; Liu, 2012; Mansour and Jeanne, 2014; Abdul Ghani et. al., 2014 and Phathara et. al., 2016). Only the individuals' personal factor that determines their level of happiness depending on their thought and interpretation.

The individual Domain was the moderate level with mean value of 2.996.This shows that self-satisfaction, work atmosphere, self-development at workplace and adaptability at workplace only contributed moderately to staff happiness. Fisher (2014), Meriam (2017) and Rashid Aziz et al., (2014) emphasized that factors including genetic, individual characters and personality influence individuals' thought and perception in determining level of happiness. Individuals with positive personality always see their working atmosphere as capable of contributing to their happiness at their organizations. They are not only positive in accepting reminders from their superior and colleagues but always feel excited when given the chance to carry out a new task.

The ability to manage and self-control will give satisfaction to staff career (Pryce and Jones, 2010). The achieved self-satisfaction will encourage individuals to work harder and have a high sense of loyalty towards the organizations (Diannisa, 2018). This opinion supports the research finding which stated that staff's self-satisfaction will in turn encourage them to recommend University A to their friends. At the same time, the research also recommends that the implementation group to be given the opportunity to show their self potential as this will influence happiness to the staff in the future.

At organizations, staff career development is implemented in two situations namely (i) staff are given the freedom to choose the type of training which is necessary to their individual needs or (ii) the organizations decide the type of training that is necessary for their future career development. Due to this, the respondents suggested that personal motivation is provided to the staff to make them happier. Among the suggestions in this context are to open opportunities for career enhancement to staff and creating new job opportunities to them. The respondents also hoped that University A to be fair and cooperative regarding staff career development.

The organizational domain only contributed at moderate level to the university staff happiness with the mean value of 2.721.Four sub domains analyzed were organizational support, atmosphere at workplace, level of task and organizational policy. The organizational management should give more focus to the organizational domain in their effort to improve staff work satisfaction. This is because the domain gives a minor influence in determining workers' happiness especially at organizations.

The atmosphere at workplace is an important factor that influences satisfaction level and increase staff motivation at organizations (Agbozo et al., 2017). Motivated individuals usually produce higher performance and subsequently easier to feel happy compares to under pressure individuals (Carr, 2004 and Fisher, 2010). Organizational work environment can be divided into three namely physical work, psychological work and social work environments Physical work environment refers to the physical aspect of organizations which include furniture and machine, furniture arrangement, temperature, air circulation, lighting and noise (Agbozo et al., 2017). According to Banburry and Berry (1998) and Sarode and Shirsath (2011), factors such as heat, noise, lighting (Chandrasekar, 2011) was found to give direct and indirect effects to cognitive performance of staff psychology. This opinion supports this research finding when staff was found to require silent working environment in order for them to work with more focused and effective.

In the context of the staff are satisfied with existing work environment especially in the aspects of lighting, air circulation and temperature at their work space. The respondents also demand for flexible and complete environment. These include the availability of healthy food, rest and relax area at every office and cafeteria at every workplace. Besides these, the respondents also suggested that the childcare service at University A to be expanded to baby nursing and education from as early as four months old. In this context, this will facilitate female staff who have 
completed their maternity leave to obtain the services nearby University A.

Organizations should be more sensitive in ensuring working conditions that are conducive to the staff in order to make them more productive and competitive. According to Yeow and Nath Sen (2003), an ergonomic workspace is a solution to the problems of weak productivity, low quality product, bad working condition and inability to compete in the global market. Even though Mansour and Jeanne (2014) stated that staff hard work cannot be used as a measure in determining their high motivation and work satisfaction, Globeforce in 2003 discovered that 85 percent of happy staff at organizations will be more efficient when they are at workplace. Zafir and Fazilah (2010) also saw that nonergonomic working condition is among the cause of stress among staff at workplace. Thus, it is important for staff and organizations to ensure workspace and working conditions comfortable when working.

Work activities and tasks are also linked to ability to influence staff happiness level. Golparvar and Abedini (2014) and Tadicet al., (2013) discovered that individuals will feel happy when they are given tasks that match their job specifications. According to Agbozo et al., (2017), working conditions could psychologically afford to offer working atmosphere that encourage cognitive activities as they would affect the emotion of the staff. In supporting the opinion, this research shows that staff that have unpleasant working experience will end up feeling demotivated to work. Siegall and Macdonald (2004) also agreed with this finding as they discovered staff with negative work experience at organizations due to several factors such as unable to finish a job on time and reprimanded by the employer publicly in front of their friends.

Head of departments need to ensure that working tasks and activities given to staff match their grade and job specifications. Other problems such as red tape, bureaucracy, directives and competency of leaders need to be seriously considered in order to create harmonious relationship between leaders and staff. Analysis shows that leadership element of superiors has a high relationship in ensuring staff happiness. Generally, the respondents expect their leaders to have good characters and apply mature leadership style and skills at organizations. According to Muda et al., (2018), leadership skills is the important element to develop leadership capability.

Organizational support such as availability of facilties, role of management and peer influence are important in ensuring staff happiness. (Meriam, 2017; Bader et al., 2013 and Siska and Ami, 2014). Relationship with colleagues and employers can be referred to as social atmosphere at workplace (Agbozo et al., 2017). Not only it refers to formal interactions between the two parties butit can also be referred to as communication style, relationship with colleagues, ability to work in group and readiness to help each other (Fisher, 2010; Siska and Ami, 2014; Anggun 2015; Abdul Raziq and Raheela, 2015 and Agbozo et al., 2017). Nevertheless, it can be witnessed that in many organizations these days employers do not respect their staff accordingly Arnetz, 1999). There were cases where to be conducive in order to make the staff to feel more

employers or superiors acted violently against their staff especially when the latter were unable to give innovative opinion when carrying out their work (Abdul Raziq and Raheela, 2015). In tandem with the opinion of Abdul Raziq and Raheela (2015), this research discovered that there were superiors who spoke roughly and scolded their staff in public. From the psychological perspective, the staff will feel embarrassed and perceive the event as a negative experience that will finally make them unhappy at their organizations.

According to Ray et al., (2013), staff inclination towards leaving their organization is low if they are in a good workplace that makes them have low stress level, not feeling threatened and feel appreciated especially by the management. In line with this statement, this research discovered that the staff feel appreciated when they are given the opportunity to discuss with their employers whenever they encounter obstacles while carrying out their work. Cottini et al., (2009) and Delfgauw et al., (2007) also agreed with Rayet et al., (2013) by stating that a good quality workplace atmosphere will avoid staff from quitting The atmosphere does not only focus on individual characters but also comprises physical, psychosocial and organizational environment.

Staff are also found to be more confident in their appearance especially when they are at their organizations. Thus it is not strange when this research discovered that University A agree and feel comfortable with the dressing ethics stipulated by the university. According to Todd (2014 and 2015), an impact of wearing uniform is it could improve discipline. In this context, wearing the corporate attire of University A for an example will influence the sense of belonging and indirectly encourages staff to cooperate in achieving the aim of the organization.

The staff was also discovered to be receptive to other policies outlined by the university such vehicle parking, attendance recording, promotional procedure. The respondents are of the opinion that it is sufficient that attendance is recorded only once a day instead of twice as being currently practiced. With the status of University A as a learning institution, its non-smoking area status does not give adverse effect to the staff. Nevertheless, despite a limited smoking area provided by the university, the staff are contented with it.

\section{CONCLUSION}

Generally, it can be said that the staff of University A require social interactions either in relationships with family, superior and colleagues or even the society itself in order to achieve happiness. The trust given to the university staff is said to be able to make them feel happy as this makes them feel appreciated. In this context, it can be said that staff will lack of self-confidence are in greater need of support from other individuals in determining their happiness. The importance of friends in the life of the staff of the university can be seen based on the score for 'being sidelined by friends'. This directly indicates that the staff 
need and appreciate their friends at the workplace. Such a situation makes the staff to easily adapt themselves at the workplace. Furthermore, the university staff also place the importance of having a more ergonomic working atmosphere that is suitable with the work burden which sometimes given to them in ad hoc manner.

\section{ACKNOWLEDGEMENTS}

This research work is supported by the Project $(\mathrm{C} 072)$ supported by UTHM.

\section{REFERENCES}

1. Amirullah, M. (2017). Factor That Lead to Happiness at The Workplace Among Academician : A Case of UiTM. Melaca. UiTM Melacca City Campus.

2. Ariati Jati. (210). Kesejahteraan Subjektif dan Kepuasan Kerja Pada Staf Pengajar (Dosen)di lingkungan Fakulti Psikologi Universiti di Ponegoro. Jurnal Psikologi Undip 8, No.2.

3. Alfarisi (2010). Hubungan Antara Kepuasan Kerja dengan Produktivitas Pada Guru. Skripsi Tidak Dipublikasikan. Pekanbaru. Fakultas Psikologi Universitas Riau.

4. Carr. (2004). Positive Psychology : The Science of Happiness and Human Strengh. New York: BrunerRoudledge.

5. Carr, J., Kelly, B., Keaton, R \& Albercht, C. (2011). Getting To Grips With Stress In The Workplace Strategies For Promoting A Healthier, More Productive Enviroment. Human Resource Management International Digest 19(4): 32-38

6. Dean, B., Diener, R. B. (2007). Positive Psychology Coaching : Putting The Science of Happiness to Work for Your Client. Canada : John Wiley \& Sons.

7. Fisher, C.D. (2010). Happiness at Work. International Journal of Management Reviews, 12, 384-412. http://dx.doi.org/10.1111/1468-0297.00570

8. Gavin, J.H. and Masson, R.O., (2004). The Virtous Organization : The Value of Happiness in The Workplace. Organizational Dynamic. 33. 379-392.

9. Jaes, M.F., Isa, K., Ahmad, A.R., and Yusoff, R.M. (2018). The Analysis of Competency Based for Indonesian Construction Labourers. International Journal of Engineering and Technology(UAE). Open AccessVolume 7, (4). 132-136.

10. Jain, A., Saeed, K., Arnaout, S. \& Kortum, E. (2012). The Psychosocial Environment at Work: An Assessment of the World Health Organization Regional Office for the Eastern Mediterranean. Eastern Mediterranean Health Journal 18(4): 325-331.

11. Lyubomirsky. (2007). The Benefit of Frequent Positive Afect : Does Happiness Lead To Success?Psychology Buletin 131. (6).

12. Meriam, O.M., (2017). Faktor-faktor Determinan Kebahagiaan Kerja Karyawan (Studi Kasus Pada PT. Bank Bukopin Tbk. Cabang Manado). Jurnal Riset Business dan Management. Vol. 5 (4). 611-630.

13. Muda, W.H.N.W., Libunao, W.H., Isa, K., Ahmad, A.R., and Yusoff, R.M. (2018). Leadership Capability Framework for the Construction Industry Leaders in Malaysia. International Journal of Engineering \& Technology, 7 (4.28), 505 -509.

14. Rashid, A. Sharif, M. Narina, A.S and Rosman, Y. (2014). Personality and Happiness Among Academician in Malaysia. Procedia-Social and Behavioral Science. Vol. 116. 4209-4212.

15. Seligman. (2005). Authentic Happiness. UK: New York.
16. Siska, W. and Ami, W. (2014). Faktor-faktor Kebahagiaan Di Tempat Kerja. Fakulti Psikologi Universiti Islam Negeri Sultan Syarif Kasim Riau.

17. Suojanen, J. (2012). Work for Happiness-Theoretical and Empirical Study Defining and Measuring Happiness at Work. Thesis. Department of Education. University of Turku.

18. Wesarat, P, Sharif, M.Y, \& Abdul Majid. A. H. (2014). Conceptual Framework of Hapinessat the Workplace. Asia Social Science.

19. Wok, S. and Hashim, J. (2014). Communication Network Organizational Contact and Communication Power in Grooming Profesional for Career Success. Malaysian Journal of Communication. 219-242.

20. Zafir M.M., Nor Liza A., \& Noor Azuan H. (2013) Stress di Tempat Kerja: Isu Global Dalam Melestarikan Organisasi : Global issues in Organization Sustainability.

21. Zafir Mohd Makhbul, Sheikh Muhamad Hizam Sheikh Khairuddin \& Nur Sa'adah Muhamad. (2018). Hubungan Stres Pekerjaan dan Produktiviti: Tinjauan Terhadap Pentadbir Fakulti Universiti Penyelidikan. Journal of Social Sciences and Humanities, 15(5), 168-180. 